Historic, Archive Document

Do not assume content reflects current scientific knowledge, policies, or practices. 

62.61

PAUL F. ROCHELLE

MORRISTOWN

NEW JERSEY

Phone 2843

Western Union Telegraph

5,000,000 Cabbage Plants

$1,000,000$ Cauliflower Plants

$2,000,000$ Celery Plants

$1,000,000$ Tomato Plants

LIB FA

rencomans.

+ JUN 261929

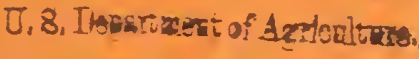

$\frac{\text { SEC. } 435^{\frac{1}{2}} \text { P. L. \& R }}{\text { U S. POSTAGE }}$

PAID

MORRISTOWn

PERMIT No.?

Hunted States best of Agriculture

Bureau of plant industry

Washuregton

d. C. 


\section{FIELD GROWN PLANTS}

CABBAGE PLANTS 5,000,000 (ready June 1st to August 15th.) All Seasons, Charleston Wakefield, Copenhagen Market, Enkhuizen Glory, Early Summer, Early Flat Dutch. All Head Early, Succession, Late Flat Dutch,

Surehead, Summer Danish Ballhead, Short Stem Danish Ballhead, American Drumhead Savoy, and Danish Round Red, $\$ 2.00$ per $1000 ; 5000 \$ 9.00 ; 500 \$ 1.25$.

RE-ROOTED CABBAGE PLANTS - $\$ 2.25$ per $1000 ; 5000 \$ 11.00 ; 500 \$ 1.50$.

I have ready now June 5 th one million and have four million coming on so I will have a continuous supply until August 15th of the stockiest and best rooted plants it is possible to grow.

Each variety is from the very best strain that is grown so far as our tests show regardless of price of seed.

CAULIFLOWER PLANTS-(All re-rooted) 1,000,000 ready June 1st to August 15th. New beds coming on each week. Early Erfurter and Snowball. $\$ 4.50$ per 1000; $5000 \$ 20.00: 500 \$ 2.50$.

I can supply you with these plants from prize winning strain of seed.

TOMATO PLANTS $-1,000,000$ ready June 25th to July 20th. John Baer, Stone, Matchless and Greater Baltimore. $\$ 3.00$ per 1000 ; Re-rooted $5000 \$ 13.00 ; 10,000 \$ 24.00$.

Fine plants about 8 inches tall with good strains and roots.

Transplanted Tomatoes, all varieties $\$ 8.00$ per 1000 .

CELERY PLANTS 2,000,000 ready July 4th to September 1st. Every plant is hardy and strong, with good roots. No poor plants shipped. Golden Self-Blanching (French Seed), White Plume, Winter Queen, Golden Heart, Giant Pascal, Easy Blanching, Golden Plume and Burpee’s Fordhook Emperor. Re-rooted $\$ 3.50$ per 1000.

Will be able to ship July 5 th as we use irrigation to make sure of keeping plants and roots growing steadily. All the celery plants are from best strains of seed.

SMALLER QUANTITIES-All orders for less than 500 plants will be $\$ 1.00$ per 100 postpaid except Potted Plants. No order accepted for less than 100 plants of any one variety.

\section{NON-WARRANTY}

While I endeavor to have all plants true to name, carefully packed and promptly shipped, I give no warranty, expressed or implied, as to description, quality, productiveness or any other matter, of any of the plants I send out, and will not in any way be responsible for the crop.

All orders accepted subject to plants being sold.

Cash must be sent with orders.

Every order received will be accepted upon these conditions only, and they must be accepted by the customer when ordering.

PHONE 2843

\section{(CLOSED EVERY SUNDAY)}

\section{WESTERN UNION TELEGRAPH}

MORRISTOWN, NEW JERSEY

\section{TESTIMONIALS}

Dudley, Mass., May tith, 1929

Paul F. Rochelle.

Dear Sir: Last year I bought some cabbage plants of you and was more than pleased with them, so please send me your free price list of Vegetable and Flower plants for 1 want to place my order at once.

R. F. D. No. 1

Respectfully yours,

C. L. Clark.

Wickatunk, N. J., April 5th, i929.

Paul F. Rochelle.

Dear Sir: Please send your wholesale price list for 1929 . We had some of your plants last year and was very pleased and will give you all plant orders this year.

\section{Yours truly,} Kleber Bros.
Easton. Me., May 20, 1929.

PAUL, l'. ROCHELLE.

Dear Sir, I am sending my tonth order for 500 re-rooted cabbage plants. 'They are always $O$. K. I want 200 summer. cabhage and 300 Winter keepers. About when can I expect them?

Mrs. Chas. E. Cahill.

Stamford Greenhouses.

PAUL F. ROCHELLE.

Dear Sir: Thanks for Tomatoes and quick service ean you do the same again and ship me 100 Zinnia mixed in paper pots \$3.50. Enclosed finded check for same thank you,

Yours truly, John G. Watson. 


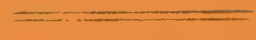

GOOD PLANTS FROM GOOD SEED

I am shipping out each day large quantities of fine planis grown from best seed to satisfied customers.

\section{PAUL F. ROCHELLE}

PHONE 2843

\section{GERANIUMS AND CHRYSANTHEMUMS IN SEASON}

ROOTED

Seedlings, Transplanted and Potted.

TOMATOES, PEPPERS, EGG PLANT, CABBAGE, CAULIFLOWER, CELERY, CALENDULAS, SALVIA, ZINNIAS, PETUNIA, AGERATUM, SNAPDRAGON, ASTERS AND OTHER PLANTS.
GROW

GOOD

PAYING

CROPS
MORRISTOWN, NEW JERSEY

WTGTERN UNION TELEGRAPH 